\title{
Hunting in northern French Guiana and its impact on primate communities
}

\author{
Benoit de Thoisy, François Renoux and Catherine Julliot
}

\begin{abstract}
The Guianas contain one of the largest single remaining tracts of undisturbed tropical rainforest in the world, but this forest and its fauna are facing increased threats. In the north of French Guiana both anthropogenic pressures and conflicts between settlements related to the use of natural resources are growing. Based on surveys in 17 forest sites we show that hunting pressure was the main factor determining current primate species richness, masking the effects of logging or forest type. Three of the larger species, the red howler monkey Alouatta seniculus, black spider monkey Ateles paniscus and tufted capuchin Cebus apella, were less abundant in hunted areas. In the areas around four settlements the harvested biomass of primates was low compared to other game species, but the harvests were close to or beyond the maximal sustainable thresholds for the red howler monkey and tufted capuchin. In French Guiana primates are either fully protected by law (the spider
\end{abstract}

monkey and white-faced saki Pithecia pithecia), or their hunting is restricted to subsistence use (howler monkey, tufted capuchin and wedge-capped capuchin Cebus olivaceus). Most hunted meat is, however, destined for sale. Current conservation policy in French Guiana is limited to legal protection for some species and areas, and laws are poorly enforced. Although large areas of forest and its wildlife are protected simply by their remoteness, there is an increasingly urgent need for the legal protection of all primate species, and the establishment of large protected areas and efficient forest management schemes to minimize the impacts of logging and hunting.

Keywords Bushmeat, French Guiana, habitats, hunting, neotropical primates, rainforest, sustainable harvest.

This paper contains supplementary material that can only be found online at http:/ /journals.cambridge.org

\section{Introduction}

The Guianas (Guyana, Suriname, French Guiana and north-east Brazil) contain one of the largest single remaining tracts of undisturbed tropical rainforest in the world, and the region has been identified as a high priority for conservation because of its high level of endemism and biodiversity (Bush, 1996). Development and urbanization in the region have historically been restricted to the coastal zone and until recently the forest areas in the central and southern parts of the region have remained largely pristine, and therefore provide an opportunity for the strategic conservation of their biological diversity, natural resources, and human cultures. However, much of the region has only recently begun to focus on conservation policy, with new initiatives such as the Iwokrama Nature Reserve in Guyana, the Central Suriname Nature

Benoit de Thoisy (Corresponding author) Association Kwata, BP 672

F-97335 Cayenne cedex, French Guiana. E-mail thoisy@kwata.org

François Renoux ENGREF, BP 316, 97379 Kourou, French Guiana.

Catherine Julliot Silvolab BP 165, 97323 Cayenne, French Guiana

Received 9 July 2003. Revision requested 19 January 2004.

Accepted 13 August 2004
Reserve, and the Tumucumaque National Park in Brazil. In French Guiana, however, where c. $90 \%$ of the territory is still covered by rainforest, no policy for biodiversity conservation has yet emerged. Current measures are limited to decrees protecting some species and areas, in what is effectively passive protection (Norconk et al., 1996) in the absence of a protected areas network (Du Toit et al., 2004) or any strategic use of renewable resources (Child, 1996). Despite having a low deforestation rate (Whitmore, 1997) direct threats are growing, mainly in the north, and include logging and widespread commercial hunting (Thoisy et al., 2000; Thoisy \& Vogel, 2002).

Primates are considered to be flagship and indicator species for the plight of tropical forests (Marsh \& Mittermeier, 1987; Johns \& Johns, 1995; Harcourt, 2000). Due to poor soil quality limiting plant productivity (Emmons, 1984), the Guianas have a relatively low primate diversity and abundance compared to the upper Amazon area. Although the eight species occurring in French Guiana have broad distributions and none are considered threatened (Rylands et al., 1997), there are increasing interactions in the north between primates and the growing human population. The seven species widely distributed in French Guiana are the black spider 
monkey Ateles paniscus (mean adult weight $8.0 \mathrm{~kg}$ ), the red howler monkey Alouatta seniculus (mean adult male and female weight 8.5 and $5.5 \mathrm{~kg}$, respectively), the tufted and wedge-capped capuchins Cebus apella and Cebus olivaceus (mean adult weight 3.5 and $3.0 \mathrm{~kg}$, respectively), the white-faced saki Pithecia pithecia (mean adult weight $1.8 \mathrm{~kg}$ ), the squirrel monkey Saimiri sciureus (mean adult weight $0.7 \mathrm{~kg}$ ), and the golden-handed tamarin Saguinus midas (mean adult weight $0.5 \mathrm{~kg}$ ). The bearded saki Chiropotes satanas is confined to the south of French Guiana and is not considered here. The only detailed information available on these primates is research on behavioural ecology in the Nouragues Nature Reserve (Julliot \& Sabatier, 1993; Zhang, 1995; Julliot, 1996, 1997; Simmen et al., 2001). The work reported here focused on the north, and aimed to (1) assess habitat features, including anthropogenic disturbance, structuring primate communities, (2) describe current hunting practices and evaluate the sustainability or otherwise of harvests, (3) underline current shortcomings in government biodiversity preservation policies and discuss conservation needs for these primates.

\section{Study area}

French Guiana is a French administrative unit of $84,000 \mathrm{~km}^{2}$ on the northern Atlantic coast of South America (Fig. 1). Human population density is low $(168,000)$, but has increased rapidly over the last two decades (Barret, 2001). Most people live on the coastal plain, where communities include Amerindians from the Kaliña, Palikur and Arawak tribes, Europeans, Creoles (intermixed descendants from slaves), Bush Negroes, Brazilians, and Asians in refugee communities originating from Laos. These various communities have distinct ways of life, economies, production systems, and relationships with the forest and its fauna. These socioeconomic and ethnic diversities have resulted in the emergence of conflicts over natural resources (Renoux, 2002).

Deforestation is limited to small patches for subsistence slash-and-burn agriculture (Renoux et al., 2003) and around legal and illegal gold mining sites, which have increased in number over the last decade (Charlet \& Boudou, 2002) and are now estimated to number 8001,000 (A. Coppel, National Forest Agency, pers. comm.). Logging is currently restricted to a $70 \mathrm{~km}$-wide belt in the north, over an area of $8,500 \mathrm{~km}^{2}$, with a selective timber harvest of $3-10 \mathrm{~m}^{3} \mathrm{ha}^{-1}$ (Bruneaux \& Demenois, 2003). Protected areas include five Nature Reserves, covering only $3 \%$ of the territory and restricted to the north (Fig. 1): Nouragues (100,000 ha; IUCN category I), Trinité (76,000 ha; category Ia), Kaw Roura (94,500 ha; category IV), Amana (14,800 ha, category IV), and Trésor $(2,500$ ha, category Ib). The establishment of a National
Park in the south, with a proposed area of 12,000 $18,000 \mathrm{~km}^{2}$, is at the planning stage. Hunting laws are restricted to a Ministerial Decree of 15 May 1986 in which the spider monkey and the two species of saki are fully protected. Other primates species can be hunted for subsistence purposes, but cannot be sold or purchased. There are no established hunting quotas or season.

\section{Methods}

Primate surveys were conducted in upland moist forest (13 sites), transition forest (two sites), marsh forest (one site) and submontane forest (one site) (Fig. 1, Table 1). The upland moist forest is the most common forest type in the Guianas, occurring on well-drained lateritic and oligotrophic soils over altitudes of 0-600 m, with high floristic diversity and endemism. Marsh forests are periodically flooded and have a relatively lower plant diversity, transition forests occur on the alluvial coastal plain, and submontane moist forests are located on lateritic crust at 500-600 m (Granville, 1988). The study sites face various degrees of human pressure, including hunting (categorized here as none, light, or heavy, determined on the basis of direct observations of footpaths, tracks, shotgun shells, and encounters with hunters), and logging (categorized here as none, recent $(<5$ years prior to the survey), or old ( $>10$ years prior to the survey), on the basis of data provided by the National Forest Agency. Sites were surveyed with line transects (Peres, 1999) by walking slowly (1-1.3 $\mathrm{km} \mathrm{hr}^{-1}$ ) along a forest track; each site was surveyed using a single track of $4-5 \mathrm{~km}$. This method has been used to assess species richness and abundance in both pristine and disturbed neotropical rainforests (Lopes \& Ferrari, 2000; Peres, 2000; Thoisy, 2000; Wright et al., 2000; Cullen et al., 2001). Methods for estimating density require a minimum number of sightings (Peres, 1999) but as this was not obtained for most sites we used relative abundance, expressed as sighting rate, for between site comparisons (Carillo et al., 2000; Lopes \& Ferrari, 2000; Wright et al., 2000). The relationships of species richness and relative abundances at each site with forest type, hunting and logging levels were examined by the Spearman rank test, using XLStat (Addinsoft, Paris, France).

Hunting was assessed in four settlements (Table 2) using interviews (Appendix) conducted over a period of 8-10 months, both during dry and wet seasons, by one of us (FR) and local key informants who lived in the villages and collected information related to hunting habits on a daily basis. A total of 206 hunters were included in the study. Data gathered included information on hunters (gender, age, economic status), hunting practices (number of hunting days, distances covered), species and number of animals harvested (including non-primate 


\section{ATLANTIC OCEAN}

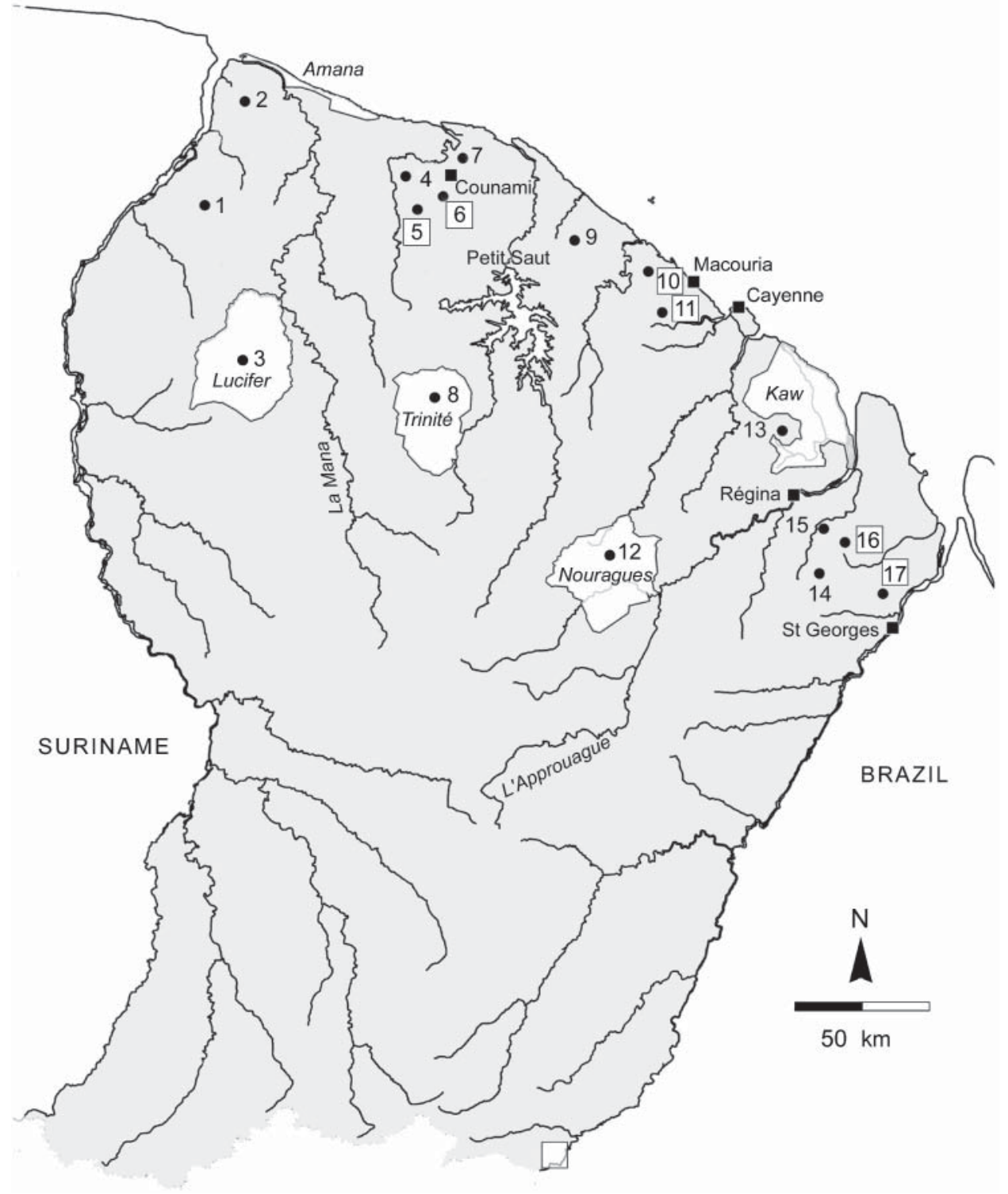

Fig. 1 French Guiana, showing main protected areas (Kaw, Trinité, Nouragues and Amana nature reserves and Lucifer biological reserve), and study sites of the primate surveys (1-17, see Table 1$)$. Numbers within boxes are sites where game harvests were evaluated (see text for details). species), the principle use of the meat (subsistence or commerce, including price), amount of game harvested, and location of harvests using a map with $5 * 5 \mathrm{~km}$ grid cells. The sum of these cells represented the total hunting area, but in order to avoid distortion from unusually long hunting trips by a limited number of hunters, we considered only the 'core' hunting area, from where 95\% of game biomass was extracted. Areas used by hunters from the four settlements were surveyed with a greater effort than other areas to obtain a larger sample of sightings, necessary for calculation of animal densities (Peres, 1999). In the hunting areas of each settlement two separate line transects were surveyed, and data pooled to allow calculation of primate densities using Distance Sampling (Buckland et al., 1993).
Sustainability of harvests in the hunting areas surrounding the four settlements was assessed using the offtake model of Robinson (2000). The observed harvest is the number of primates harvested annually in the hunting area. This observed offtake is compared to a maximal offtake, which is the number of primates that could be hunted in the same area with no significant risk of overharvesting. Calculation of this maximal offtake requires data on the density of primates, size of the hunting area, and a threshold value derived from life history and species growth rate data. For primates this threshold value is $3 \%$ of the population, and offtake is calculated as density * catchment core area size ${ }^{*} 0.03$. (Robinson, 2000). As far as possible we attempted to test the accuracy of data we collected in the field before applying the model. 
Table 1 The 17 sites in which primates were surveyed (numbers refer to locations in Fig. 1), with forest type, occurrence of any logging, mean transect length and total survey length.

\begin{tabular}{llllr}
\hline Site & Forest type & Logging & Mean transect length $(\mathrm{km} \pm \mathrm{SE})$ & Total survey length $(\mathrm{km})$ \\
\hline 1. Maurice & upland moist forest & none & $4.1 \pm 0.5$ & 91 \\
2. Coswine & marsh forest & none & $4.0 \pm 0.5$ & 100 \\
3. Lucifer & submontane moist forest & none & $3.5 \pm 0.1$ & 110 \\
4. Counami T & upland moist forest & none & $4.8 \pm 0.3$ & 94 \\
5. Counami A & upland moist forest & none & $5.0 \pm 0.2$ & 104 \\
6. Counami B & upland moist forest & recent & $4.8 \pm 0.0$ & 101 \\
7. Patagai & upland moist forest & old & $5.4 \pm 0.0$ & 113 \\
8. Trinité & upland moist forest & none & $4.1 \pm 0.2$ & 93 \\
9. Barthod & transition forest & old & $4.0 \pm-0.1$ & 92 \\
10. Matiti & transition forest & old & $4.6 \pm 0.0$ & 101 \\
11. Balata & upland moist forest & none & $5 \pm 0.1$ & 100 \\
12. Nouragues & upland moist forest & none & $3.5 \pm 0.0$ & 91 \\
13. Kaw & upland moist forest & none & $4.0 \pm 0.1$ & 150 \\
14. Régina T & upland moist forest & none & $4.9 \pm 0.2$ & 101 \\
15. Régina 1 & upland moist forest & none & $5.0 \pm 0.1$ & 100 \\
16. Régina 2 & upland moist forest & none & $5.1 \pm 0.3$ & 102 \\
17. St Georges & upland moist forest & none & $4.5 \pm 0.5$ & 97 \\
\hline
\end{tabular}

Table 2 Details and results of interviews conducted in four settlements (see Fig. 1 for locations) in northern French Guiana.

\begin{tabular}{llll}
\hline & Counami & Tonate & Régina \\
\hline Communities* & $\mathrm{Br}, \mathrm{BN}, \mathrm{Am}, \mathrm{Cr}, \mathrm{Eu}, \mathrm{As}$ & $\mathrm{Am}$ & $\mathrm{Br}, \mathrm{BN}, \mathrm{Am}, \mathrm{Cr}, \mathrm{As}$ \\
No. hunters interviewed & 28 & 41 & 32 \\
Study length & 8 months & 8 months & 8 months \\
Primary reason for hunting & subsistence & commerce & commerce \\
Secondary reason for hunting & commerce & subsistence & subsistence \\
\hline
\end{tabular}

*Br, Brazilians; BN, Bush Negroes; Am, Amerindians; Cr, Creoles; Eu, Europeans; As, Asians

Firstly, the observed harvest could have been underestimated. By cross-referencing information obtained from different local people, we obtained evidence that the key informant of each settlement underestimated harvests by c. $20 \%$, mainly because of the numerous routes used to access each hunting area. Secondly, we focused on the size of the hunting areas. The $5 * 5 \mathrm{~km}$ map grid cells were an efficient way to identify the location of harvests during interviews, but hunters also reported that, in most cases, the total distance of most hunting trips did not exceed 5 $\mathrm{km}$. Within each hunting area, we identified all tracks and rivers used by hunters, and using a geographic information system we demarcated a potentially hunted area of $2.5 \mathrm{~km}$ width along each of these features. Superimposition of this area on a map of all grid cells used by hunters showed that the latter method may overestimate the harvested area by up to $10 \%$ (Fig. 2).

\section{Results}

\section{Primate richness and abundances}

The tufted capuchin, howler monkey, white-faced saki, and golden-handed tamarin are wide-ranging in French Guiana, and were recorded in all forest habitats. The wedge-capped capuchin was observed only in upland forests, and the squirrel monkey was restricted to marsh and transition forests. The spider monkey was observed only in upland forest. The number of primate species sighted during surveys was 3-6 per site, and was negatively correlated with hunting pressure (Spearman rank $\left.r_{\mathrm{s}}=-0.831, \mathrm{P}<0.001\right)$.

Degree of hunting pressure and primate relative abundances and mean group sizes are given in Table 3. There were negative correlations between relative abundances and hunting pressure for three of the larger species, the howler monkey $\left(r_{\mathrm{s}}=-0.809, \mathrm{P}<0.0001\right)$, spider monkey $\left(r_{\mathrm{s}}=-0.890, \mathrm{P}<0.0001\right)$ and tufted capuchin $\left(r_{\mathrm{s}}=-0.804\right.$, $\mathrm{P}<0.0001)$ but not for other species, and a negative correlation between mean group size and hunting pressure for the tufted capuchin $\left(r_{\mathrm{s}}=-0.207, \mathrm{P}=0.02\right)$.

\section{Primates as game species}

Hunting is either for subsistence, hobby, or commerce, although selling any primate species is prohibited by law. Table 4 shows the size of the total area used by each of the four settlements for hunting, and of the core area where hunting is concentrated. Interviews showed that 


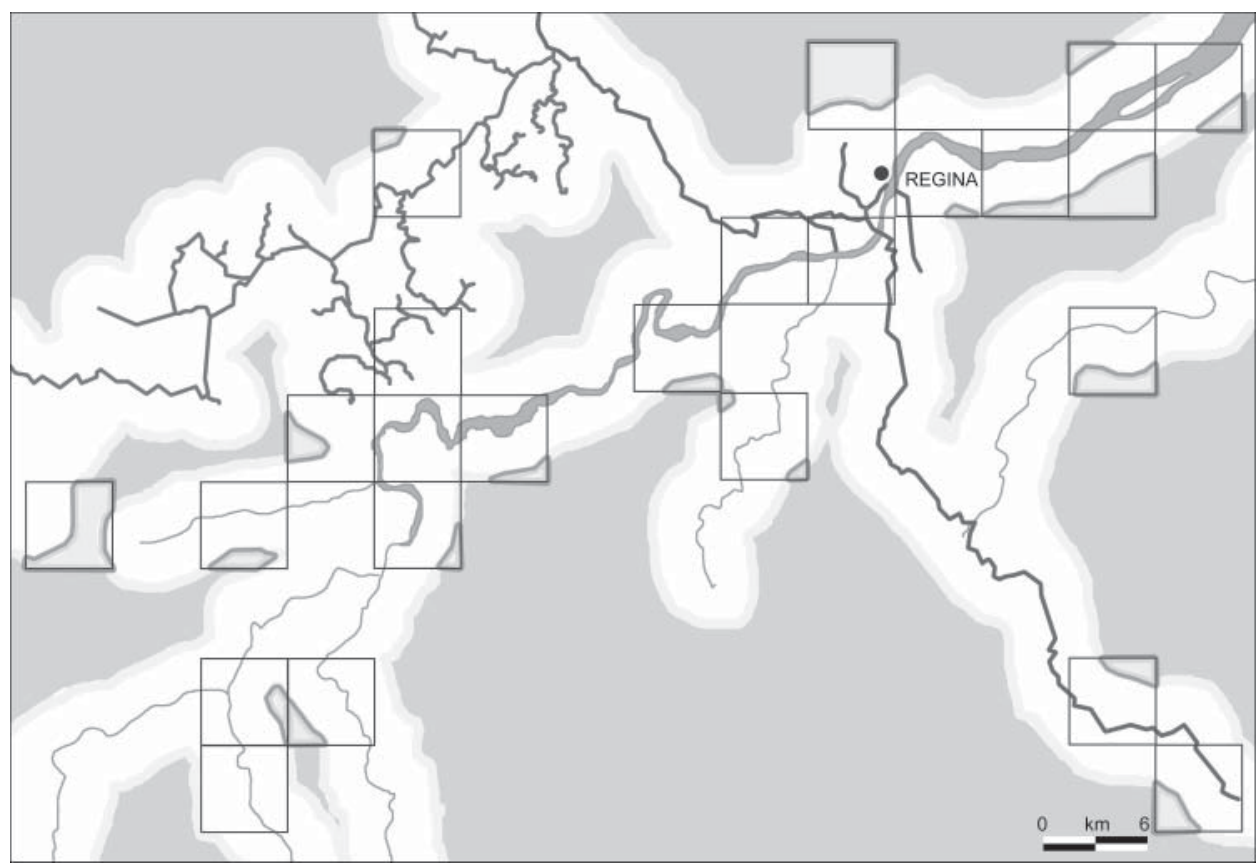

Fig. 2 Use of forest areas by hunters of the community of Regina. Rivers and tributaries are in light grey, and tracks and roads in dark grey. Each square is a $5 * 5 \mathrm{~km}$ area from which game was harvested, as reported during interviews. Areas in white lie within a distance of $2.5 \mathrm{~km}$ of access routes. Within each $5 * 5 \mathrm{~km}$ square the area that lies at a distance of $>2.5 \mathrm{~km}$ (the maximum distance travelled by most hunters) from an access route is highlighted. These areas represented c. $10 \%$ of the area of the grid squares, and this is therefore the potential overestimation of the hunting area.

five species may be consumed, although black spider and howler monkeys and the tufted capuchin are the more commonly hunted. The total harvested game biomass per hunter is $100-330 \mathrm{~kg}$ per year; the contribution of primates to this biomass depends on the human communities rather than on the destination of the meat. Amerindians (the Palikur tribe at Tonate and St Georges, the Kaliña tribe at Counami) hunt proportionally more primates than other communities, either for subsistence or commerce, although the latter is opportunistic. In contrast, the harvest of primates by professional hunters from Régina and St Georges, working in close relationships with markets, is low. Prices of primate meat are similar to the prices of other game species (for example at St Georges, red howler and black spider monkeys are $2.5 \$ \mathrm{~kg}^{-1}$ and peccaries and tapir $\left.2.8 \$ \mathrm{~kg}^{-1}\right)$. In Régina and St Georges the sale of game meat provides a high income for hunters compared to incomes from other forms of employment available in the settlements.

The offtake model was applied to the recorded harvests after making two corrections to the data: an increase of the harvest by $20 \%$ and a reduction of the harvested area by $10 \%$. As calculated primates densities were expressed as a mean $\pm 95 \%$ confidence interval they resulted in a range for the theoretical maximal sustainable harvest for each site hunting area and each species (Table 5). Harvests that are within or greater than this range are likely to be unsustainable. In areas hunted around two of the settlements, Tonate and Counami, harvests of red howler monkey and wedge-capped capuchins appear to be unsustainable.

\section{Discussion}

Hunting pressure is the main factor structuring primate communities in northern French Guiana. In species, such as primates, that are particularly sensitive to harvesting, hunting pressure conceals the influence of other factors such as forest productivity (Peres, 2000) and other human disturbances (Lopes \& Ferrari, 2000). Spider monkeys, howler monkeys and capuchins are strongly affected by overhunting (Bodmer et al., 1997) because of their low rates of reproduction, gregarious social structure, and non-cryptic behaviour. Significant reductions in the biomass of large-bodied primates have been documented in numerous neotropical sites subject to hunting pressure (Sussman \& Phillips-Conroy, 1995; Peres, 1997; Carillo et al., 2000; Lopes \& Ferrari, 2000; Wright et al., 2000; Bennett et al., 2001). Local extinctions of frugivorous species in French Guiana will have expected consequences on seed dispersal and predation, plant species composition, and predator-prey interactions (Redford, 1992).

Other than the filling of the Petit Saut hydroelectric dam in 1994-1995, which resulted in the flooding of 


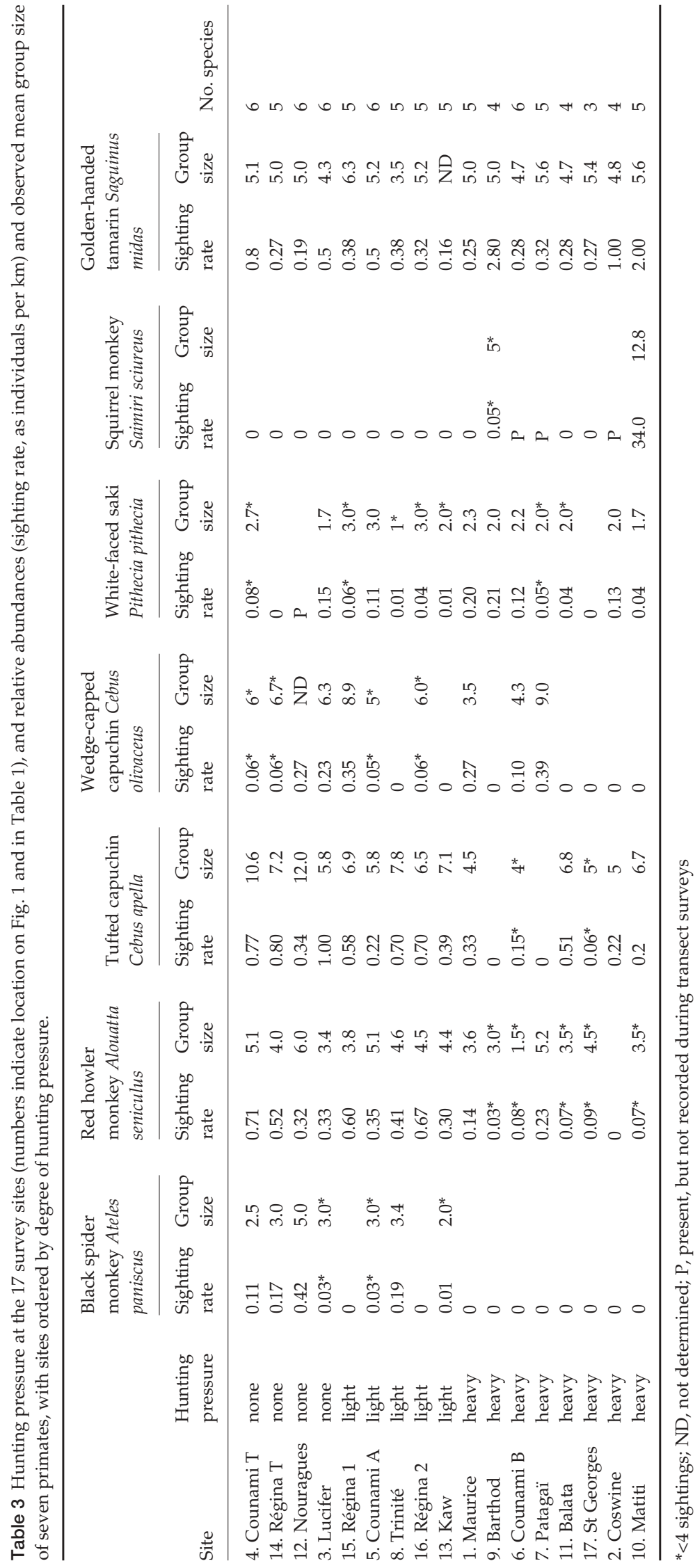


Table 4 Primates harvested by people in four settlements (see Fig. 1 for locations) in northern French Guiana.

\begin{tabular}{|c|c|c|c|c|}
\hline Sites & Counami & Tonate & Régina & St Georges \\
\hline Survey numbers (see Table 1 ) & 5,6 & 10,11 & $15,16^{1}$ & $16,17^{1}$ \\
\hline Total hunting area $\left(\mathrm{km}^{2}\right)$ & 525 & 650 & 600 & $1,250^{2}$ \\
\hline Core area from which $95 \%$ of biomass extracted $\left(\mathrm{km}^{2}\right)$ & 250 & 400 & 475 & 950 \\
\hline Total biomass harvested per hunter per year $(\mathrm{kg})$ & 145.2 & 100.8 & 212.4 & 332 \\
\hline Mean income per hunter per month $(\bullet)$ & - & 27 & 40 & 74 \\
\hline Primate biomass/total game biomass (\%) & 1.9 & 6.4 & 0.5 & 0.3 \\
\hline Primate biomass sold $(\%)$ & 26 & 75 & 70 & 66 \\
\hline \multicolumn{5}{|l|}{ No. harvested per year } \\
\hline Black spider monkey & 1 & & 7 & 1 \\
\hline Red howler monkey & 8 & 35 & & 5 \\
\hline Tufted capuchin & 4 & 47 & 12 & 18 \\
\hline Wedge-capped capuchin & & 6 & & \\
\hline White-faced saki & & 3 & & \\
\hline
\end{tabular}

${ }^{1}$ Survey 16 crossed an area used by people of both Régina \& St Georges

${ }^{2} 40 \%$ of the area is in Brazil

Table 5 The offtake model (Robinson, 2000) applied to harvested primates. Corrected actual harvests (see text for details) that are within or greater than the maximal offtake range are in bold.

\begin{tabular}{|c|c|c|c|c|c|}
\hline & & Counami & Tonate & Régina & St Georges \\
\hline \multirow{4}{*}{$\begin{array}{l}\text { Mean density } \pm \\
\left.\text { 95\% CI (no. } \mathrm{km}^{-2}\right)\end{array}$} & Black spider monkey & & & $1.8^{*}$ & $1.8^{*}$ \\
\hline & Red howler monkey & $3.2 \pm 1.9$ & $1^{*}$ & & $3.1 \pm 1.8$ \\
\hline & Tufted capuchin & $3.7 \pm 2.7$ & $5.2 \pm 3.4$ & $4.6 \pm 2.9$ & $4.5 \pm 2.7$ \\
\hline & White-faced saki & & $2.0 \pm 1.5$ & & \\
\hline \multirow{4}{*}{$\begin{array}{l}\text { Maximal } \\
\text { sustainable } \\
\text { harvest } \pm \text { range } \\
\left(\text { no. } \mathrm{yr}^{-1}\right)\end{array}$} & Black spider monkey & & & $23^{*}$ & $46^{*}$ \\
\hline & Red howler monkey & $22 \pm 12$ & $11^{*}$ & & $83 \pm 48$ \\
\hline & Tufted capuchin & $24 \pm 19$ & $56 \pm 37$ & $58 \pm 38$ & $117 \pm 75$ \\
\hline & White-faced saki & & $20 \pm 15$ & & \\
\hline \multirow{4}{*}{$\begin{array}{l}\text { Corrected }(+20 \%) \\
\text { actual harvest } \\
\left(\text { no. } \mathrm{yr}^{-1}\right)\end{array}$} & Black spider monkey & & & 8 & 2 \\
\hline & Red howler monkey & 10 & 35 & & 6 \\
\hline & Tufted capuchin & 5 & 52 & 14 & 22 \\
\hline & White-faced saki & & 4 & & \\
\hline
\end{tabular}

*No confidence interval or range as data set is small

$365 \mathrm{~km}^{2}$ of forest (Vié, 1999), logging is the main pressure on forest in northern French Guiana. Because the logging is selective, however, damage is limited. Four tree species account for more than $70 \%$ of timber volume: Dicorynia guiananensis, Vouacapoua americana, Ocotea rubra and Qualea rosea. Although primates are partly dependent on these species (Hammond et al., 1996) we did not find any evidence of the direct impact of logging activities on primate communities. However, logging results in increased accessibility to upland forest (Peres \& Lake, 2003). As most game extraction occurs within $2.5 \mathrm{~km}$ of access routes, we estimated potential accessibility along rivers and tributaries and along the $2,400 \mathrm{~km}$ of existing logging roads, and found that $80 \%$ of the $8,500 \mathrm{~km}^{2}$ of forests managed for logging are accessible and therefore at risk of faunal depletion (Wilkie et al., 1992). In most cases inaccessible areas are too patchily distributed to play a major role as refuges or as sources for population restocking (Laurance et al., 2000; Novaro et al., 2000). The impact of hunting pressure acts synergetically with habitat disturbance (Johns, 1985; Peres, 2001), and the two sites where sustainable thresholds for primate hunting have been surpassed are also those where hunting areas are organized around logging tracks.

Traditional Amerindian communities often have a high proportion of primates in their diet (Vickers, 1991; Mena et al., 2000). In a Wayãpi village in southern French Guiana (Renoux, 1998) the total annual game biomass harvested was $190 \mathrm{~kg}$ per hunter. This was comparable to harvests that we recorded amongst northern Amerindian communities, except that in the south primates accounted for $15 \%$ of the harvest rather than $0.5-6 \%$. Improvement of socioeconomic conditions, as has happened in the north, contributes to a decrease in pressure from subsistence harvesting (Jorgenson, 2000), and lower primate densities, from overhunting, may also have resulted in the hunting of other game species.

The current policy for conservation of biodiversity and natural resources in French Guiana still follows a colonial 
type model (Child, 1996), with measures restricted to decrees for the protection of some areas and species. Strictly protected areas are an essential element for sustainable hunting (Peres, 2000), but they require adequate surveillance, education and public awareness. The countries of the Guianas require a network of protected areas of the size, design, and means appropriate for the maintenance of their ecological functions and the conservation of their flora and fauna. For primates, because of their poor ability to sustain harvesting, an additional and immediate necessity is their full protection by law. Poaching, although limited, will otherwise continue to represent a threat.

The government of French Guiana currently owns $92 \%$ of the country's forests. This is a guarantee against large-scale threats and accounts for the relatively healthy status of the forests. However, the national land laws do not recognize the rights of land use by indigenous communities. Conservation, management and sustainable use of natural resources, and requests concerning the rights and traditional lifestyles of the local communities in their use of forest products (Hill, 2002), remain poorly considered in government policies in French Guiana. It will be necessary to integrate these matters into forthcoming forest and environment laws to prevent conflicts harmful to wildlife and conservation. An additional concern is that pressures for the occupation and development of the southern areas of French Guiana will undoubtedly increase in the future. Gold mining is occurring on most rivers and tributaries throughout the country, and is becoming an increasingly significant force in destabilizing traditional socioeconomic structures.

In summary, hunting is the main pressure on primates in French Guiana and, for at least some species, appears to be unsustainable. Habitat loss is occurring at only a low rate, although a significant part of game harvesting is facilitated by selective logging, which provides access to previously inaccessible areas. Comprehensive legal protection is required for the country's primate species, but conservation efforts need to be urgently focused on habitat management. This will facilitate protection of primates and provide opportunities for improving the sustainable use of other forest species.

\section{Acknowledgments}

We are grateful to Anthony Rylands for his extensive improvement of a preliminary version of this paper. Primate surveys (BdT and CJ) were funded by the Office National des Forêts, the Direction Régionale de l'Environnement, the Zoological Parks of La Vallée des Singes, France, and Doué la Fontaine, France. Ethnoecological studies (FR) were funded by the European Union (DG VIII) and the French Ministry of Environment, with contributions from the Office
National de la Chasse et de la Faune Sauvage. We thank P. Joubert for GIS assistance.

\section{References}

Barret, J. (ed.) (2001) Atlas Illustré de la Guyane. IRD éditions, Paris, France.

Bennett, C.L., Leonard, S. \& Carter, S. (2001) Abundance, diversity, and patterns of distribution of primates of the Tapiche river in Amazonian Peru. American Journal of Primatology, 54, 119-126.

Bodmer, R.E., Eisenberg, J.F. \& Redford, K.H. (1997) Hunting and the likelihood of extinction of Amazonian mammals. Conservation Biology, 11, 460-466.

Bruneaux, O. \& Demenois, J. (2003) Aménagement forestier et exploitation en forêt tropicale humide guyanaise. Revue Forestière Française, LV, 260-272.

Buckland, S.T., Anderson, D.R., Burnham, K.P. \& Laake, J.L. (eds) (1993) Distance Sampling: Estimating Abundance of Biological Populations. Chapman \& Hall, London, UK.

Bush, M.B. (1996) Amazonian conservation in a changing world. Biological Conservation, 76, 219-228.

Carillo, E., Wong, G. \& Cuarón. A.D. (2000) Monitoring mammal populations in Costa Rican protected areas under different hunting restrictions. Conservation Biology, 14, 1580-1591.

Charlet, L. \& Boudou, A. (2002) Cet or qui file un mauvais mercure. La Recherche, 359, 52-59.

Child, G. (1996) Realistic 'game laws'. Oryx, 30, 228-229.

Cullen, L., Bodmer R.E. \& Valladares-Padua, C. (2001) Ecological consequences of hunting in Atlantic forest patches, São Paulo, Brazil. Oryx, 35, 137-144.

Du Toit, J., Walker, B.H. \& Campbell, B.M. (2004) Conserving tropical nature: current challenges for ecologists. Trends in Ecology and Evolution, 19, 21-17.

Emmons, L.H. (1984) Geographic variation in densities and diversities of non flying mammals in Amazonia. Biotropica, 16, 210-222.

Granville, J.J. de (1988) Phytogeographical characteristics of the Guianan forests. Taxon, 37, 578-594.

Hammond, D.S., Gourlet-Fleury, S., van der Hout P., ter Steege V. \& Brown, V.K. (1996). A compilation of known guianan timber trees and the significance of their dispersal mode, seed size, and taxonomic affinity to tropical rain forest management. Forest Ecology and Management, 83, 99-116.

Harcourt, A.H. (2000) Coincidence and mismatch of biodiversity hotspots: a global survey for the order Primates. Biological Conservation, 93, 163-175.

Hill, C.M. (2002) Primate conservation and local communities ethical issues and debates. American Anthropologist, 104, 1184-1194.

Johns, A.D. (1985) Differential detectability of primates between primary and selectively logged habitats and implication for population surveys. American Journal of Primatology, 8, 31-36.

Johns, A.G., Johns, B.G. (1995) Tropical forests and primates: long term coexistence. Oryx , 29, 205-211.

Jorgenson, J.P. (2000) Wildlife conservation and game harvest by Maya hunters in Quintina Roo, Mexico. In Hunting for Sustainability in Tropical Forests (eds J.G. Robinson \& E.L. Bennett), pp. 251-266. Colombia University Press, New York, USA.

Julliot, C. (1996) Fruit choice by the red howler monkeys (Alouatta seniculus) in a tropical rainforest. American Journal of Primatology, 40, 261-282. 
Julliot, C. (1997) Impact of seed dispersal by red howler monkeys (Alouatta seniculus) on the seedling population in the understorey of tropical rainforest. Journal of Ecology, 85, 431-440.

Julliot, C. \& Sabatier D. (1993) Diet of the red howler monkey (Alouatta seniculus) in French Guiana. International Journal of Primatology, 14, 527-550.

Laurance, W.F., Vasconcelos, H.L. \& Lovejoy, T.E. (2000) Forest loss and fragmentation in the Amazon: implications for wildlife conservation. Oryx, 34, 39-45.

Lopes, M.A. \& Ferrari, S.E. (2000) Effects of human colonization on the abundance and diversity of mammals in Eastern Brazilian Amazonia. Conservation Biology, 14, 1658-1665.

Marsh, C.W. \& Mittermeier, R.A. (eds) (1987) Primate Conservation in the Tropical Rainforest. Alan R. Liss, New York, USA.

Mena, P., Stallings, J.R., Regalado, J. \& Cueva, R. (2000) The sustainability of current hunting practises by the Huaorani. In Hunting for Sustainability in Tropical Forests (eds J.G. Robinson \& E.L. Bennett), pp. 58-78. Colombia University Press, New York, USA

Norconk, M.A, Sussman, R.W. \& Philips-Conroy, J. (1996) Primates of the Guyana shield forests: Venezuela and the Guianas. In Adaptative Radiations of Neotropical Primates (eds M.A. Norconk, A.L. Rosenberg \& P.A. Garber), pp. 69-83. Plenum Press, New York, USA.

Novaro, A.J., Redford, K.H. \& Bodmer, R.E. (2000) Effects of hunting in source-sink systems in the Neotropics. Conservation Biology, 14, 73-721.

Peres, C.A. (1997) Primate community structure at twenty western Amazonian flooded and unflooded forests. Journal of Tropical Ecology, 13, 381-405.

Peres, C.A. (1999) Generalized guidelines for standardized line-transect surveys of tropical forest vertebrates. Neotropical Primates, 7, 11-16.

Peres, C.A. (2000) Effects of subsistence hunting on vertebrate community structure in Amazonian forests. Conservation Biology, 14, 240-253.

Peres, C.A. (2001) Synergetic effects of subsistence hunting and habitat fragmentation on Amazonian forest vertebrates. Conservation Biology, 15, 1490-1505.

Peres, C.A. \& Lake, I. (2003). Extent of non-timber resource extraction in tropical forests: accessibility to game vertebrates by hunters in the Amazon basin. Conservation Biology, 17, 521-535.

Redford, K.H. (1992) The empty forest. BioScience, 42, 412-422.

Renoux, F. (1998) Se nourrir à Trois Sauts: analyse diachronique de la prédation chez les Wayãpi du Haut-Oyapock. Journal d'Agriculture Traditionnelle et de Botanique Appliquée, 40, 167-180.

Renoux, F. (2002) Ethnoécologie des Pratiques de Chasse en Guyane. Unpublished Report, Tropical Ecosystems Programs, Ministry of Environment, Paris, France.

Renoux, F., Fleury, M., Reinette, Y., Grenand, P. \& Grenand, F. (2003) L'agriculture sur brûlis dans les bassins du Maroni et de l'Oyapock: dynamique d'adaptation aux contraintes spatiales. Revue Forestière Française, LV, 236-259.

Robinson, J.G. (2000) Calculating maximum sustainable harvests and percentage offtakes. In Hunting for Sustainability in Tropical Forests (eds J.G. Robinson \& E.L. Bennett), pp. 521-524. Colombia University Press, New York, USA.

Rylands, A.B., Mittermeier, R.A. \& Rodriguez-Luna, E. (1997) Conservation of neotropical primates: threatened species and an analysis of primate diversity by country and region. Folia Primatologica, 68, 134-160.
Simmen, B., Julliot, C., Bayart F. \& Pagès, E. (2001) Diet and population densities of the primate community in relation to fruit supplies. In Nouragues: Dynamics and Plant-animal Interactions in a Neotropical Rainforest (eds F. Bongers, P. Charles-Dominique, P.M. Forget \& M. Théry), pp. 89-101. Kluwer Academic Publisher, Dordrecht, Netherlands.

Sussman, R.W. \& Phillips-Conroy, J.E. (1995) Survey of the distribution and density of primates of Guyana. International Journal of Primatology, 16, 561-591.

Thoisy, B. de (2000) Line-transects: sampling application to a rainforest in French Guiana. Mammalia, 64, 101-112.

Thoisy, B. de, Massemin, D. \& Dewynter, M. (2000) Hunting impact on a neotropical primate community: a preliminary case study in French Guiana. Neotropical Primates, 8, 141-144.

Thoisy, B. de \& Vogel, I. (2002) Status of lowland tapirs (Tapirus terrestris) in French Guiana: a preliminary assessment. Tapir Conservation (IUCN/Species Survival Commission Tapir Specialist Group Newsletter), 11, 18.

Vickers, W.T. (1991) Hunting yields and game composition over ten years in an Amazonian indian territory. In Neotropical Wildlife Use and Conservation (eds J.G. Robinson \& K.H. Redford), pp. 53-81. University of Chicago Press, Chicago, USA.

Vié, J.C. (1999) Wildlife rescues - the case of the Petit Saut hydroelectric dam in French Guiana. Oryx, 33, 115-126.

Whitmore, T.C. (1997) Tropical forest disturbance, disappearance, and species loss. In Tropical Forest Remnants: Ecology, Management and Conservation of Fragmented Populations (eds W.F. Laurance \& R.O. Bierregaard Jr), pp. 3-12. The University of Chicago Press, Chicago, USA.

Wilkie, D.S., Sidle, J.G. \& Boundzanga, G.C. (1992) Mechanized logging, market hunting and a bank loan in Congo. Conservation Biology, 6, 570-580.

Wright, S.J., Zeballos, H., Domínguez, I., Gallardo, M.M., Moreno, M.C. \& Ibánez, R. (2000) Poachers alter mammal abundance, seed dispersal, and seed predation in a neotropical forest. Conservation Biology, 14, 227-239.

Zhang, S.Y. (1995) Activity and ranging patterns in relation to fruit utilization by brown capuchins (Cebus apella) in French Guiana. International Journal of Primatology, 16, 489-507.

\section{Appendix}

The appendix for this article is available online at http:/ / journals.cambridge.org

\section{Biographical sketches}

Benoit de Thoisy is a conservation biologist working for Kwata, a non-governmental organization in French Guiana. Projects developed by Kwata are focused on threatened species and natural resources management, including game and timber harvests.

François Renoux has worked for several French scientific institutions in French Guiana during the last 8 years. Specializing in human ecology, he has studied relationships between the social organization of human communities and foraging for natural resources in neotropical rainforests.

Catherine Julliot has worked since 1988 on the relationships between animals, especially primates, and natural forest regeneration and biodiversity in tropical rainforests of French Guiana, Gabon and Madagascar. 